\title{
The Impact of Gluten-Free Diet on the Lifes of Individuals with Celiac Disease: A Turkish Perspective
}

\author{
Glutensiz Diyetin Çölyak Hastalarının Yaşamları Üzerine Etkisi: Türkiye Bakış Açısı
}

\section{Yeliz Serin ${ }^{1}$, Gamze Akbulut ${ }^{2}$}

Geliş tarihi/Received: 02.07.2020 • Kabul tarihi/Accepted: 15.03.2021

\begin{abstract}
Aim: The aim of this study was to evaluate the influence of gluten-free (GF) diet on social lives of patients.

Subjects and Method: The design of the study was descriptive and cross-sectional. The questionnaire was designed as an online form. The online survey was announced on an online social support network called "Turkey Celiac Association" which has about 6000 members. The patients older than 18 years and diagnosed by a specialist doctor were enrolled in the study.

Results: The study was completed with a total of 464 patients (114 males and 350 females). Difficulties often expressed by at least $50 \%$ of the respondents include: "limited purchasing power due to the high cost of gluten-free products (59.3\%)", "lack of accessibility to gluten-free products in grocery stores (51.9\%)", "lack of accessibility to gluten-free products in local stores (54.1\%)", and "inability to find shops and restaurants selling gluten-free foods during travelling (49.1\%)".

Conclusion: Today, educating patients on a gluten-free diet is the cornerstone of treatment. In this article, the priorities of gluten-free nutrition education by the dietitians and recommendations of solution for the barriers affecting the sustainability of the diet are emphasized.
\end{abstract}

Keywords: Celiac disease, gluten free diet, adult, education

\section{ÖZET}

Amaç: Bu çalışmanın amacı glutensiz diyetin hastaların sosyal yaşamları üzerindeki etkisini değerlendirmektir.

Bireyler ve Yöntem: Bu çalışma kesitsel ve tanımlayıcı niteliktedir. Çalışmada kullanılan anket formu elektronik formatta düzenlenerek, yaklaşık 6000 üyesi olan "Türkiye Çölyaklılar Birliği” isimli sosyal destek ağı aracılı̆̆ı ile hastalara ilan edilmiştir. Hekim tarafından çölyak tanısı alan, 18 yaş ve üzeri bireyler çalışmaya dahil edilmiştir.

Bulgular: Çalışma toplam 464 (114 erkek, 350 kadın) birey ile tamamlanmıştır. Katılımcıların en az \%50'si, glutensiz ürünlerin maliyetinin yüksek olmasının bu ürünleri satın alma gücünü etkilediğini (\%59.3), marketlerde her zaman glutensiz ürün bulunmadığını (\%51.9), yerel mağazalarda glutensiz ürünlerin her zaman bulunmadığını (\%54.1) ve seyahatlerde glutensiz besin satan mağaza ve restoran bulma (\%49.1) konularında zorluk yaşadıklarını ifade etmişlerdir.

1. İletişim/Correspondence: Department of Nutrition and Dietetics, Gazi University, Faculty of Health Sciences, Turkey

E-posta: dytyelizserin@gmail.com • ๑ https://orcid.org/0000-0002-1524-0651
2. Department of Nutrition and Dietetics, Gazi University, Faculty of Health Sciences, Turkey • 으 https://orcid.org/0000-0003-0197-1573 
Sonuç: Günümüzde hastaların glutensiz diyet eğitimi tedavinin temelini oluşturmaktadır. Bu makalede; diyetisyenlerin glutensiz diyet eğitimi kapsamında yer alması gereken temel başlıklar ile diyetin sürdürülebilirliğini etkileyen engeller için çözüm önerileri vurgulanmıştır.

Anahtar kelimeler: Çölyak hastalığl, glutensiz diyet, yetişkin, eğitim

\section{INTRODUCTION}

Celiac disease (CD) is an autoimmune disease triggered by the ingestion of gluten in genetically susceptible individuals, which leads to the damage of the small intestine (1). It is also characterized by intestinal and/or extraintestinal manifestations. The number of celiac disease diagnoses has increased in recent past years and according to a screening study, the total prevalence of the disorder is around 1\% (2). In Turkey, it is estimated that the prevalence of celiac disease is between one percent to three per thousand, which corresponds to almost 250 to 750 thousand patients (3). Until the late 1970s, the suspicion of celiac disease was based mainly on clinical symptoms such as diarrhea, malabsorption and weight loss. Later on, spe $\neg$ cific diagnostic tools, such as intestinal biopsy, enabled better diagnosis of CD (4). Celiac disease is a multifactorial disorder and its development is controlled by a com $\neg$ bination of genetic and environmental risk factors. The underlying predisposing genes among patients with CD primarily consist of 2 HLA class II genes (HLADQ2) and HLA-DQ8 (5).

A gluten-free diet (GFD) is the only effective treatment for celiac disease, as there are currently no medications that can reliably and safely prevent the mucosal damage caused by exposure to gluten (6). A strict GFD means that the daily intake of gluten should be less than $20 \mathrm{mg} /$ day. This corresponds to one percent of a slice of bread. (7). A lifelong GFD is difficult to sustain owing to the restricted availability and higher cost of gluten-free food alternatives, poorer quality of their taste, flavor, texture and mouthfeel, small levels of unex-pected gluten contaminations, cultural practices and usual nutrition habits leading to a substan $\neg$ tial social burden (8). Thus, living with celiac disease could be very diffucult for patients. As far as we know, there is no study to determine the difficulties in the adherence of gluten-free diet in Turkey. The present study aimed to evaluate the influence of CD on social life and the difficulties experienced in daily foodrelated situations.

\section{SUBJECTS AND METHOD}

The design of the current study was descriptive and cross-sectional. The questionnaire was designed as an online form. For the online survey, Google Docs program was used to design and collect the online data. Google Docs is a word processor, part of a free, web-based software office suite offered by Google within its Google Drive Service (9). In order to prevent duplication data, only one response entry was allowed from each e-mail address. So, it was ensured that respondents filled out answers in accordance with guidelines that set before.

The online survey was announced on an online social support network called "Turkey Celiac Association" which has about 6000 members. The network site was free and accessible to the public with internet access. An announcement about the survey was published on the site between 01 June 2015 and 01 January 2016 August. The sample size of this study was consisted of participants who filled the electronic questionnaire fixed to the website between announcement dates. The announcement included a description of the research study, as well as the link to the online survey. The online questionnaire was developed by reviewed scientific literature and in consultation with the Ankara Celiac Association.

The questionnaire mainly consisted of four sections on demographics variables (age, weight, height), participants' general health status (age of diagnosis, 
comorbid diseases), questions about screening and diagnosis situation with regard to celiac disease in families and questions related to the adherence of gluten-free diet. Individuals over 18 years and over were diagnosed by a specialist doctor and eligible subjects for following a gluten-free diet were admitted to participate in the survey. The electronic informed consent form was attached to the survey. The study protocol was approved by the Gazi University Ethics Committee (18.06.2015/06).

\section{Statistical Analyses}

Statistical analyses were performed using the SPSS software version 22.0. The variables were investigated using visial (histograms, probability plots) and analytical method (Kolmogrov-Smirnow) to determine whether or not they are normally disturbed. Descriptive analyses were presented using mean and standard deviation for normally distributed variables, while medians and inter quartile range (IQR) were presented for the non-normally distrubuted and ordinal variables. Categorical data were described using percentages. The Student's t test was performed between two independent groups and the one-way ANOVA was used to compare more than two independent groups to compare whether the values were normally distributed. The Mann-Whitney $\mathrm{U}$ test was used to compare the values that were not distributed normally between two independent groups. A p value of less than 0.05 was considered to show a statistically significiant result.

\section{RESULTS}

The study was completed with a total of 464 patients (114 males and 350 females) who are older than 18 years and diagnosed by a specialist physician. The mean age of the patients was $34.8 \pm 11.0$ years. The mean (SD) Body Mass Index (BMI) was $23.7 \pm 3.9 \mathrm{~kg} / \mathrm{m}^{2}$ in men and $22.3 \pm 4.6 \mathrm{~kg} / \mathrm{m}^{2}$ in women. Patients who follow a gluten-free diet for less than one year had a lower BMI than the ones following a gluten-free diet between 1-5 years and above 5 years $(p<0.05)$ (Table 1).

Out of total, $18.5 \%$ of the participants had another person diagnosed with celiac disease in their families and $58.2 \%$ of them was first-degree relatives (Table 2).

Sixty-five percent of the respondents had one or more comorbid disease and the distributions of the comorbid disease were $49.7 \%$ iron deficiency anemia, 23.2\% depression, 21.9\% thyroid disease, $18.2 \%$ migraine and $16.2 \%$ thyroid diseases (Figure 1).

Difficulties often expressed by at least $50 \%$ of the respondents include: "limited purchasing power due to the high cost of gluten-free products (59.3\%)", "lack of accessibility to gluten-free products in grocery stores (51.9\%)", "lack of accessibility to gluten-free products in local stores (54.1\%)", and "inability to find shops and restaurants selling gluten-free foods during travelling (49.1\%)".

Table 1. Demographics and clinical features of participations

\begin{tabular}{|c|c|c|c|c|}
\hline \multirow{2}{*}{ Variables } & Male (n=114) & Female $(n=350)$ & Total $(n=464)$ & \multirow{2}{*}{$\mathbf{p}$} \\
\hline & $\overline{\mathrm{X}} \pm$ SS (Min-Max) & $\overline{\mathrm{X}} \pm$ SS (Min-Max) & $\overline{\mathrm{X}} \pm$ SS (Min-Max) & \\
\hline Age (years) & $35.2 \pm 11.4(18-63)$ & $34.6 \pm 10.9(18-81)$ & $34.8 \pm 11.0(18-81)$ & .625 \\
\hline \multirow[t]{2}{*}{ BMI $\left(\mathbf{k g} / \mathbf{m}^{2}\right)$} & $23.7 \pm 3.9(14.9-34.3)$ & $22.3 \pm 4.6(14.2-60.2)$ & $22.6 \pm 4.5(14.2-60.2)$ & $.004^{*}$ \\
\hline & Median (IQR) & Median (IQR) & Median (IQR) & \\
\hline Age at diagnosis (years) & $30.5(18.3)$ & $29.0(14.3)$ & $29.0(16.0)$ & .725 \\
\hline Duration of gluten free diet (months) & $36.0(71)$ & $30(60)$ & $35.0(60)$ & .106 \\
\hline \multirow[t]{2}{*}{ Changes in BMI during gluten-free diet } & $<1$ year $(\mathrm{n}=135)$ & $1-5$ years $(n=185)$ & $>5$ years $(n=144)$ & $\mathrm{P}$ \\
\hline & $\overline{\mathbf{X}} \pm \mathbf{S S}$ & $\overline{\mathbf{X}} \pm \mathbf{S S}$ & $\overline{\mathbf{X}} \pm \mathbf{S S}$ & \\
\hline BMI $\left(\mathrm{kg} / \mathrm{m}^{2}\right)$ & $21.7 \pm 3.5$ & $23.0 \pm 4.7$ & $22.9 \pm 4.9$ & $.03 *$ \\
\hline
\end{tabular}

BMI: Body Mass Index, This analysis was performed using Student T test and One-way ANOVA for independent parametric samples and The Mann-Whitney U test for independent non-parametric samples. $p<.05$ considered significiant. 
Table 2. Screening and diagnosis situation with regard to celiac disease in families $(n=464)$

\begin{tabular}{lll}
\hline Celiac disease in the familiy & $\mathbf{n}$ & $\mathbf{\%}$ \\
\hline An individual diagnosed with celiac disease in the family before & & \\
Yes & 86 & 18.5 \\
No & 378 & 81.5 \\
Degree of relationship of who diagnosed with celiac disease in the family before & $\mathbf{n = 8 6}$ & \\
$\quad$ First degree relatives & 50 & 58.2 \\
Second degree relatives & 36 & 41.8 \\
Screening of family members of the participants with serology tests & $\mathbf{n = 4 6 4}$ & \\
Yes & 198 & 42.7 \\
No & 266 & 57.3 \\
\hline
\end{tabular}

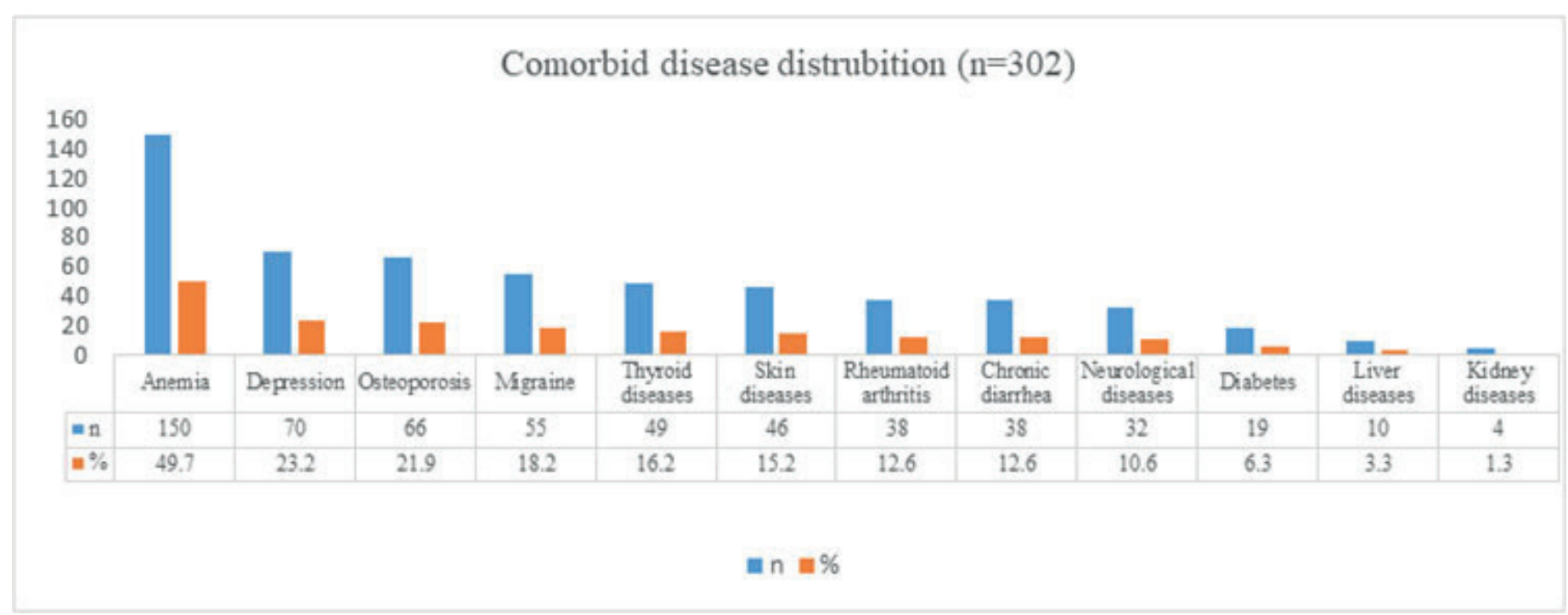

Figure 1. Comorbid diseasase distruption in patients with celiac disease $(\mathrm{n}=302)$

Figure legend. The figure shows the proportion of individuals with one or more comorbid disease apart from celiac.

\section{DISCUSSION}

Celiac disease is a lifelong disease and the prevalence of diagnosis is increasing. The last total number of patients registered in the health information systems of the Ministry of Health is 68.123 (3). Studies in recent years have shown that celiac patients unable to adapt to a gluten-free diet have malnutrition and significantly low quality of life (QoL) (10-14).

The studies on celiac disease in Turkey were mostly aimed to determine the epidemiology and clinical course of the disease, nutritional status and quality of life of patients (15-19). As far as we know, there are no reports on patients having difficulty adhering to a gluten-free diet. Therefore, to identify the difficulties encountered by patients during gluten-free diet may be a guide for the future studies that can be done in this area.

For long years, celiac disease has been thought as a malabsorption situation associated with classical celiac disease symptoms which are often thought to occur in children admitted to various clinics with symptoms of diarrhea, growth-retardation, failure to weight gain and/or lack of body weight (19). However, with the widespread use of serological tests, recent studies have shown that BMIs of patients could be higher than the normal range (18.5-24.9 kg/ $\mathrm{m}^{2}$ ) at baseline or later stages of the disease (19-21). Therefore, it should not be forgotten that individuals with normal or higher BMI values may also have 
Table 3. Gluten free diet related difficulties experienced often by celiac patients $(n=464)$

\begin{tabular}{|c|c|c|}
\hline Items & $\mathbf{n}$ & $\%$ \\
\hline \multicolumn{3}{|l|}{ Purchasing gluten-free foods } \\
\hline Limited purchases due to cost of commercially prepared GF foods & 275 & 59.3 \\
\hline Lack of accessibility to GF foods in the markets & 241 & 51.9 \\
\hline Lack of accessibility to GF foods in every local stores & 246 & 53.0 \\
\hline Inadequacy of variety of gluten free foods & 235 & 50.6 \\
\hline Concerned about inadequate food labels & 148 & 31.9 \\
\hline Insufficient information from the manufacturer or sales staff & 129 & 27.8 \\
\hline Tastelessness of gluten free foods & 96 & 20.7 \\
\hline All of them & 215 & 46.3 \\
\hline \multicolumn{3}{|l|}{ Gluten-free food preparation } \\
\hline Limited GF choices & 134 & 28.9 \\
\hline Having to cook more often & 121 & 26.1 \\
\hline Frustrating effect of preparing favourite recipes with GF flours & 132 & 28.4 \\
\hline More difficulty preparing GF meals than normal foods & 95 & 20.5 \\
\hline All of them & 218 & 47.0 \\
\hline \multicolumn{3}{|l|}{ Eating with family/friends } \\
\hline Feeling sad due to attitudes related to celiac disease of people & 188 & 40.5 \\
\hline Having the ideas that a little gluten will not hurt patients & 235 & 50.6 \\
\hline Feeling like a burden because of $\mathrm{CD}$ & 146 & 31.5 \\
\hline Avoid going to social events involving food & 189 & 40.7 \\
\hline Feeling embarrassed because of special dietary needs & 143 & 30.8 \\
\hline Suspect that family/friends are afraid to invite someone for meals & 131 & 28.2 \\
\hline Have difficulty to refuse gluten-containing foods offered by social environment & 114 & 24.6 \\
\hline Lack of understanding dietary requirements of patients by family or friends. & 145 & 31.3 \\
\hline All of them & 151 & 32.5 \\
\hline \multicolumn{3}{|l|}{ Eating in restaurants } \\
\hline Limited gluten-free restaurants & 208 & 44.8 \\
\hline Limited food choices at restaurants & 176 & 37.9 \\
\hline Chefs inexperienced in prepearing GF food & 183 & 39.4 \\
\hline Hesitating to ask contents of the menu in a restaurant or cafe. & 65 & 14.0 \\
\hline All of them & 218 & 47.0 \\
\hline \multicolumn{3}{|l|}{ Eating at school/work } \\
\hline Limited choices in the cafeteria or refectory & 207 & 44.6 \\
\hline Difficulty having to bring own food for lunches & 207 & 44.6 \\
\hline Feeling hurt when people are indifferent to the dietary needs & 139 & 30.0 \\
\hline Feeling stressful because of business lunches & 81 & 17.5 \\
\hline All of them & 182 & 39.2 \\
\hline \multicolumn{3}{|l|}{ Travelling } \\
\hline Having some difficulties abroad due to inadequate label information in GF* foods. & 42 & 9.1 \\
\hline Feeling sorry not tasting local flavors & 153 & 33.0 \\
\hline Difficulty in finding shops and restaurants that sell GF food & 228 & 49.1 \\
\hline Difficulty in carrying GF food when travelling & 251 & 54.1 \\
\hline All of them & 167 & 36.0 \\
\hline
\end{tabular}

Individuals responded to the same question more than once and percentages were calculated according to the total number. *GF: gluten fr 
celiac risk (22). In a study comparing BMI values of celiac patients with healthy populations, the mean BMI values of male patients were found to be $21.6 \pm 2.9$ $\mathrm{kg} / \mathrm{m}^{2}$ and female patients $23.1 \pm 4.0 \mathrm{~kg} / \mathrm{m}^{2}$, which are significantly lower than the healthy participants (23). In this study, the mean BMI values of men and women were determined as $21.7 \pm 3.5 \mathrm{~kg} / \mathrm{m}^{2}$ and $23.0 \pm 4.7 \mathrm{~kg} / \mathrm{m}^{2}$, respectively (Table 1). According to the World Health Organization (WHO) classification, both groups have normal body weight (24).

Gluten-free diet has been the most effective treatment for celiac disease until now. However, it has been noted that the gluten-free diet has some deficiencies. Especially, it was reported that a gluten-free diet has inadequate fiber and folate, with higher fat, sugar and gluten-free food contents (25). Although adaptation to a gluten-free diet is essential for celiac patients, inadequate composition of gluten-free products can lead to some health problems. In a study, it was found that nearly $30 \%$ of patients with normal weight at the time of diagnosis shifted into metabolic syndrome just one year after starting to a gluten-free diet (26). According to the three-year follow up results of another study, it was reported that $22 \%$ of patients following a gluten-free diet gained weight, increasing their BMI >2 pts (22). In this study, patients who followed a gluten-free diet for less than one year have a lower BMI than those who followed a gluten-free diet between 1-5 years and above 5 years (Table 1 ). So, an in-depth nutritional assessment and follow-up with a specialist dietitian is essential to help prevent weight gain and other health problems related to gluten free diets.

Celiac disease has an autoimmune component (TG2). For this reason, other autoimmune diseases frequently accompany to celiac disease. This is explained by the similarity of HLA haplotypes (15,27). Mostly, Type I Diabetes Mellitus(DM) and autoimmune thyroiditis are comorbiditied with celiac disease. In a study, specific changes attributed to celiac disease were detected in the small intestine biopsy of $8 \%$ of the patients diagnosed with type 1 Diabetes (15). Individuals with celiac disease may be at risk for autoimmune diseases or who have autoimmune diseases may be at risk for celiac disease (27). Remarkably, $30 \%$ of celiac patients have one or more autoimmune disease, while this rate is around 3\% for the general population (28). In this study, it was determined that the most common comorbid disease in celiac patients is anemia (65.1\%) (Figure 1). In particular, the proximal part of the small intestine is where iron is absorbed most. Therefore, the inflammation degree of this part is correlated with serum iron level (6). Because of this, clinicians should consider celiac disease as a possible cause of anemia in all patients with iron deficiency anemia of obscure origin, even in menstruating women. Serologic screening tests should be performed in premenopausal women with iron deficiency anemia, especially when anemia is refractory to oral iron treatment (29).

Celiac disease has hereditary features and more than one person in the same family can have celiac disease. The prevalance of celiac disease has been reported to be $75-80 \%$ in monozygotic twins, $15-20 \%$ in the first relatives of celiac patients $(15,30)$. The reason for this is the level of human leukocyte antigens (HLA), which are strongly associated with celiac disease (15). It is reported that $95 \%$ of celiac patients have HLA-DQ2 allele, whereas $5 \%$ of patients have HLA-DQ8 allele (30). In this study, $18.5 \%$ of the study group had a relative diagnosed with celiac disease before (58.2\% of them are first-degree relatives).

There are studies reporting that celiac patients have some difficulties during a gluten-free diet. In a study, it was reported that patients complained about lack of gluten free food labels, preparing gluten-free foods at frequent intervals, to have limited food choices and people's idea that a little gluten could not be harmful for patients (10). In another study, individuals adhering to a gluten free diet, expressed themselves as isolated from social life (29). Similarly, Black and Orfila (2011) reported that patients often face with limited gluten free food choices when traveling and did not get sufficient information from food labels (31). In addition, prepackaged gluten-free foods have been reported to cost more than their gluten containing 
equivalent (10). In this study, difficulties often expressed by at least $50 \%$ of the respondents include: "limited purchasing power due to the high cost of gluten-free products (59.3\%)", "lack of accessibility to gluten-free products in grocery stores (51.9\%)", "lack of accessibility to gluten-free products in local stores (54.1\%)", and "inability to find shops and restaurants selling gluten-free foods during travelling (49.1\%)" (Table 3). Because of these reasons, encouragement of domestic production can balance the price, increase thevariety and facilitate the accessibility of gluten-free products. It is hoped that, with increased competition in the marketplace, the price differential between gluten-free foods and the foods that they replace will be reduced. However, difficulties experienced in restaurants could be greatly reduced by training chefs and restaurant staff about the principles of gluten free diets as well as educating them on how to avoid food contamination with gluten during food preparation. Such training will help those with celiac disease maintain a normal social life $(10,31,32)$. The patients may consume a wide range of common foods such as meat, fish, milk products, vegetables, and fruits, but they should be aware of numerous foods that contain "hidden" sources of gluten, such as thickened sauces and soups, puddings and sausages (7).

As stated earlier, there are many factors that affect compliance with a gluten-free diet. For this reason, it is needed a multidisciplinary approach to solve the problems. Educating patients about gluten free diet is the cornerstone of treatment. Nutrition education priorities should include the principles of the glutenfree diet, foods to avoid, label reading, gluten-free food options and brands, cross contamination, nutrients at risk, nutritional adequacy, adequate fibre and protein intake. In addition, the barriers to the sustainability of the diet should be solved. The factors that may affect the sustainability are access to glutenfree products, cost of gluten-free products, access to a dietitian for appropriate advice, availability of glutenfree products, the tasteless of gluten free products. multidisciplinary team could offer some solutions to authorized people. For example, patients could be educated regularly by dietitians about gluten free diets at primary care health services. On the other hand, various attempts can be made by food producers in order to produce reliable, cheaper and more delicious products. Celiac patients may be forced to eat at least one meal outside the home because of their social status. Particularly, in institutions catering food for celiac patients, separate nutrition sites where there is no risk of cross contamination should be provided and gluten-free food alternatives should be offered. In addition, the safety of gluten-free products and the reliability of labeling information can be guaranteed by the government laws and manufacturer companies should be controlled periodically by competent authorities. Access to gluten-free products can be facilitated and social support can be given to individuals by increasing celiac awareness in the community. At this stage, the support of family and friends is very important for patients on a glutenfree diet. For this purpose, it will be useful to plan and carry out various activities, trainings, awareness campaigns by health professionals, public institutions and organizations, non-governmental organizations and celiac associations.

Conflict of interest: The authors declare that they have no conflict of interest.

Acknowledgements: We thank the participants involved in this study.

Fundig: The author(s) received no financial support for the research, authorship, and/or publication of this article.

Ethics approval: The study protocol was approved by the Gazi University Ethics Committee (18.06.2015/06).

Authors'contributions: Y.S. and G.A conducted the literature review and G.A. organized and drafted the manuscript. All authors have read and approved the final manuscript.

\section{REFERENCES}

1. Roka V, Potamianos SP, Kapsoritakis AN, Yiannaki EE, Koukoulis GN, Stefanidis I, et al. Prevalence of coeliac disease in the adult population of central Greece. Eur J Gastroenterol Hepatol. 2007;19(11):982-7.

2. Lohi S, Mustalahti K, Kaukinen K, Laurila K, Collin P, 
Rissanen $\mathrm{H}$, et al. Increasing prevalence of coeliac disease over time. Aliment Pharmacol Ther. 2007;26(9):1217-25.

3. T.C. Sağlık Bakanlığı Halk Sağlığı Genel Müdürlüğü. Çölyak ve Görülme Sıklığı Erişim: https://hsgm.saglik. gov.tr/tr/metabolizma-ve-colyak/\%C3\%A7\%C3\%B6lyak$\mathrm{v}$ e $-\mathrm{g} \%$ C $3 \%$ B 6 r $\%$ C $3 \%$ B C l m e s\%C4\%B1kl\%C4\%B1\%C4\%9F\%C4\%B1.html. Erişim tarihi: 1 Mayıs 2020.

4. Koehler P, Wieser H, Konitzer K. Celiac disease-a complex disorder. In: Koehler P, Wieser H, Konitzer K, editors. Celiac disease and gluten: multidisciplinary challenges and opportunities [Internet]. Elsevier: Academic Press; 2014. [cited 2020 Apr 15]. Chapter 1. Avaliable from: https://www.elsevier.com/books/celiacdisease-and-gluten/koehler/978-0-12-420220-7.

5. Lionetti E, Castellaneta S, Francavilla R, Pulvirenti A, Tonutti E, Amarri S, et al. Introduction of gluten, HLA status, and the risk of celiac disease in children. $\mathrm{N}$ Engl J Med. 2014;371(14):1295-303.

6. Nadhem ON, Azeez G, Smalligan RD, Urban S. Review and practice guidelines for celiac disease in 2014. J Postgrad Med. 2015;127(3):259-65.

7. Koehler $\mathrm{P}$, Wieser $\mathrm{H}$, Konitzer $\mathrm{K}$. Treatment of celiac disease. In: Koehler P, Wieser H, Konitzer K, editors. Celiac disease and gluten: multidisciplinary challenges and opportunities [Internet]. Elsevier: Academic Press;2014. [cited 2020 Apr 15]. Chapter 3. Avaliable from: https://www.elsevier.com/books/celiac-diseaseand-gluten/koehler/978-0-12-420220-7

8. Hallert C, Grännö C, Grant C, Hulten S, Midhagen G, Ström $\mathrm{M}$, et al. Quality of life of adult coeliac patients treated for 10 years. Scand J Gastroenterol. 1998;33(9):933-8.

9. Eaton SE. How to use google forms: a step-by-step guide [Internet]. Canada: Werklund School of Education Research \& Publications; 2011 [cited 2020 Sep 9] p.5-24 Available from: http://hdl.handle.net/1880/51935=http:// dx.doi.org/10.11575/PRISM/31635

10. Zarkadas M, Dubois S, MacIsaac K, Cantin I, Rashid M, Roberts K, et al. Living with coeliac disease and a glutenfree diet: A Canadian perspective. J Hum Nutr Diet. 2013;26(1):10-23.

11. Lee A, Ng D, Diamond B, Ciaccio E, Green P. Living with coeliac disease: survey results from the USA. J Hum Nutr Diet. 2012;25(3):233-8.

12. Häuser W, Gold J, Stein J, Caspary WF, Stallmach A. Health-related quality of life in adult coeliac disease in Germany: results of a national survey. Eur J Gastroenterol Hepatol. 2006;18(7):747-54.

13. O'Leary C, Wieneke P, Buckley S, O'Regan P, Cronin CC, Quigley EM, et al. Celiac disease and irritable boweltype symptoms. Am J Gastroenterol. 2002;97(6):1463-7.

14. Fera T, Cascio B, Angelini G, Martini S, Guidetti CS. Affective disorders and quality of life in adult coeliac disease patients on a gluten-free diet. Eur J Gastroenterol Hepatol. 2003;15(12):1287-92.

15. Aydoğdu S, Tümgör G. Çölyak hastalığı. Güncel Pediatri. 2005;3(1):47-53.

16. Yönal O, Özdil S. Çölyak hastalığı. Güncel Gastroentoloji. 2014;18(1):93-100.

17. Aksan A, Mercanllgil SM, Häuser W, Karaismailoğlu E. Validation of the Turkish version of the celiac disease questionnaire (CDQ). Health Qual Life Outcomes. 2015;13(1):82.

18. Ceylan N, Demiroren K. The prevalence of celiac disease in healthy school children in Van City, east of Turkey: a screening study using a rapid test. Med Sci Discov. 2016;3(3):130-3.

19. Balamtekin N, Aksoy C, Baysoy G, Uslu N, Demir H, Köksal G, et al. Is compliance with gluten-free diet sufficient? Diet composition of celiac patients. Turk J Pediatr. 2015;57(4):374.

20. Reilly NR, Aguilar K, Hassid BG, Cheng J, DeFelice AR, Kazlow P, et al. Celiac disease in normal-weight and overweight children: clinical features and growth outcomes following a gluten-free diet. J Pediatr Gastroenterol Nutr. 2011;53(5):528-31.

21. Whitehead C. Obesity and coeliac disease: possible effects of the gluten-free diet. Gastroenterol Nurs. 2013;11(3):31-6.

22. Kabbani T, Goldberg A, Kelly C, Pallav K, Tariq S, Peer A, et al. Body mass index and the risk of obesity in coeliac disease treated with the gluten-free diet. Aliment Pharmacol Ther. 2012;35(6):723-9.

23. Olén O, Montgomery SM, Marcus C, Ekbom A, Ludvigsson JF. Coeliac disease and body mass index: a study of two swedish general population-based registers. Scand J Gastroenterol. 2009;44(10):1198-206.

24. World Health Organisation (WHO). Body mass index BMI. Available at: http://www.euro.who.int/en/healthtopics/disease-prevention/nutrition/a-healthy-lifestyle/ body-mass-index-bmi.Accesed April 15, 2020.

25. Shepherd SJ, Gibson PR. Nutritional inadequacies of the gluten-free diet in both recently-diagnosed and longterm patients with coeliac disease. J Hum Nutr Diet. 2013;26(4):349-58.

26. Tortora R, Capone P, De Stefano G, Imperatore N, Gerbino $\mathrm{N}$, Donetto S, et al. Metabolic syndrome in patients with coeliac disease on a gluten-free diet. Aliment Pharmacol Ther. 2015;41(4):352-9.

27. Kaukinen K, Collin P, Mäki M. Celiac disease-a diagnostic and therapeutic challenge. Duodecim. 2010;126(3):24554.

28. Mereiles L, Li M, Loo D, Liu E. Celiac disease and intestinal endocrine autoimmunity In: Eisenbarth GS, editors. Immunoendocrinology: Scientific and clinical 
aspects [Internet]. Springer: Humana Press; 2011 [cited 2020 Sep 9] p. 535-45. Available from: https:/link. springer.com/book/10.1007/978-1-60327-478-4.

29. Çekın A, Çekın Y, Sezer C. Celiac disease prevalence in patients with iron deficiency anemia. Turk J Gastroenterol. 2012;23(5):490-5.

30. Fabris A, Segat L, Catamo E, Morgutti M, Vendramin A, Crovella S. HLA-G 14 bp deletion/insertion polymorphism in celiac disease. Am J Gastroenterol.
2011;106(1):139-44.

31. Black J, Orfila C. Impact of coeliac disease on dietary habits and quality of life. J Acad Nutr Diet. 2011;24(6):5827.

32. Karajeh MA, Hurlstone DP, Patel TM, Sanders DS. Chefs' knowledge of coeliac disease (compared to the public): A questionnaire survey from the United Kingdom. Clin Nutr. 2005;24(2):206-10. 